\title{
E-BRIEF
}

April 19, 2017

\section{Surge Capacity: Selling City-owned Electricity Distributors to Meet Broader Municipal Infrastructure Needs}

by

Steven Robins

- Many of Canada's cities - particularly in Alberta and Ontario - own local electricity distribution companies. However, municipal ownership does not affect electricity prices or service, leaving no compelling public policy rationale for ownership.

- Municipalities in Ontario, along with Edmonton and Calgary, could sell all or part of their equity stakes in electricity companies - worth between $\$ 15$ billion and $\$ 20$ billion - and invest the proceeds in critical municipal infrastructure.

- Other governments should take actions to encourage cities to realize the value of these electricity assets, with the province of Ontario eliminating or rebating to cities punitive taxes on electricity company sales and the federal government remitting back to provinces any corporate income tax they receive from newly taxable electricity companies, provided the proceeds are reinvested in infrastructure.

Canada's cities are looking to finance significant investment in infrastructure. Collectively, Canada's municipalities own equity stakes worth potentially \$15-\$20 billion in local electricity distribution companies (LDCs). There is no compelling public policy rationale for continued municipal ownership, and the private sector has shown a strong willingness to invest in LDCs. Municipalities could sell their equity stakes and recycle the proceeds into priority infrastructure projects.

The author thanks Benjamin Dachis, Chris Benedetti, Andrew Claerhout, Akash Deep, Jim Hinds, John Macomber, Grant Sprague and several anonymous reviewers for advice and helpful comments on an earlier draft. The author retains responsibility for any errors and the views expressed here. 


\section{Figure 1: Ownership of Canadian LDCs}

Ownership Model

\# of LDCs $\quad \%$ of Customers

- Municipally owned LDCs in Ontario plus large Alberta municipally owned LDCs: Edmonton's EPCOR and Calgary's Enmax.

57

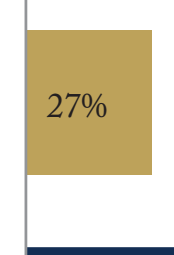

- Crown corporations providing distribution services (or partially privatized crown corporation in the case of Hydro One).

- Other municipally owned LDCs in BC, AB, SK, $\mathrm{QC}, \mathrm{NB}$, or PEI - too small for further analysis in this study.

- $100 \%$ privately held LDCs in BC, AB, ON, NWT, $\mathrm{YK}$, province-wide in NS, PEI, and NL - primary

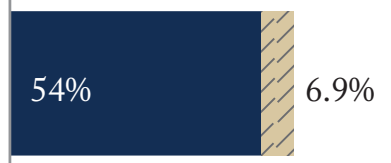
equity investors are Fortis and ATCO.

Focus of Study Others Hydro One

Source: Author's calculations from Ontario Energy Board (OEB), 2015 Yearbook of Electricity Distributors, company annual reports. The assumption is that all Ontario mergers with signed memoranda of understanding (MoUs) have been successfully completed.

Some cities are already considering selling their equity stakes. Toronto city officials, for example, have contemplated a partial equity sale of Toronto Hydro to finance infrastructure investment (City of Toronto 2016). Peterborough, Orillia, Haldimand, and Woodstock have already sold their LDCs to Hydro One (Hydro One 2016; Kovach 2016). In 2009, Edmonton spun off the electricity generating assets owned by EPCOR, its LDC (Iveson 2009a).

In this study, I focus on the potential for equity sales in Ontario and Alberta, where municipalities have significant LDC ownership. Both provinces already have regulators that set the rates for municipally and privately owned LDCs. These regulators have demonstrated an ability to protect consumer interests in those parts of the provinces where private utilities operate. The rates they set for utilities where municipalities sell their equity stake would not change. These 57 utilities represent 27 percent of Canadian electricity customers. The remainder of Canada's electricity distribution is provided by provincially owned electricity companies serving 61 percent of customers - companies that often also own transmission and generation assets - while the private sector serves 10 percent of customers. A further 2.6 percent of customers are served by 22 municipally owned LDCs. These LDCs are beyond the scope of this study (Figure 1). 
Under the current regulatory structure, Ontario equity sales would transfer significant wealth from municipalities to the provincial and federal government, while in Alberta they would transfer resources from consumers to the provincial and federal government. Alberta, Ontario and the federal government should remove taxation barriers for municipalities in accessing this value, without harming consumers.

\section{The Potential for Change}

\section{Existing Mixed Ownership Globally}

Most jurisdictions have some role for private distribution companies, which they manage by price-setting, rateof-return regulation. In Canada, some residents of British Columbia, Alberta, Ontario, and Newfoundland receive their power from a privately owned LDC, while in PEI and Nova Scotia, 100 percent of electricity distribution is privately provided. In the United Kingdom, electricity distribution is provided through 14 privately owned distribution licensees, which were sold initially in the 1990s (OFGEM 2013). In Australia, the states of South Australia and Victoria have privatized their electricity distribution, but in the other states and territories it is provided by state-owned companies (Kerin 2014).

In the United States, 80 percent of power travels over privately owned transmission or distribution lines ("Electricity Transmission and Distribution" National Academy of Sciences 2009). New Zealand has a system similar to that in Ontario, with small LDCs (roughly 30) that are owned primarily by city councils or local consumer trusts. However, the LDC serving Auckland, the largest city, is 25 percent privately owned, and two of the other largest LDCs have been sold to institutional investors. In all cases, where an investor-owned utility operates a distribution network, it is accompanied by a price-setting regulator to protect consumers. Alberta and Ontario already have independent agencies regulating private-sector electricity distributors.

\section{Industry Consolidation}

Ontario has the potential for cost-savings through LDC consolidation that would be shared between owners and ratepayers. The province currently has 60 electricity distributors, down from 307 in the late 1990s: Hydro One; three LDCs owned by Fortis; an electricity cooperative; and 55 municipally owned LDCs. ${ }^{1}$ Some municipal LDCs have sold 10 percent stakes to private investors. Ontario's 2012 review of the LDC sector recommended further consolidation down to just 8-12 regional LDCs - by legislation, if necessary - in order to achieve potential economies of scale in operating cost, financing, regulatory approvals, and unnecessary duplication. The review also pointed to successful mergers in the 2000s which saw cost reductions exceeding 10 percent (Elston, Laughren, and McFadden 2012). The province, however, declined to legislate and maintained a policy of encouraging voluntary mergers.

Since 2012, 13 LDCs have exited the market either through mergers or by sale to Hydro One - most notably the merger of four LDCs in the western Greater Toronto Area (GTA) and another of three LDCs in the eastern GTA, assuming all pending transactions close. Fyfe, Garner, and Vegh (2013) questioned the economies of scale

1 This analysis assumes that the proposed "GTA West" Powerstream / Horizon / Enersource / Hydro One Brampton, the "GTA East" Veridian / Whitby / Oshawa, and the Thunder Bay / Kenora mergers, and the sale of Peterborough distribution are completed. 
from forced consolidation and, instead, suggested removing barriers to voluntary consolidation through privatesector ownership. Although the potential for some further savings through consolidation is there, any significant savings will require further merger activity among the largest players - the five largest LDCs that serve 70 percent of Ontario customers. Involving private investment could help catalyze further cost-saving mergers, which would help reduce electricity prices.

Block (2016) argues that Ontario's privately owned utilities have higher costs than do the publicly owned utilities. However, this analysis ignores other factors driving utility costs, such as population density, which may do more to drive cost differences.

\section{Expansion and Use of Public Capital}

At least three LDCs - Hydro Ottawa, EPCOR, and Enmax - have expanded significantly beyond their original jurisdictions. Hydro Ottawa operates hydroelectric dams throughout eastern Ontario and upstate New York (Hydro Ottawa Holding Inc. 2015). EPCOR provides electricity distribution to about 230,000 customers outside Edmonton, and water and wastewater to more than one million people across Western Canada, Arizona, and New Mexico (EPCOR 2016). In 2009, EPCOR took its generating assets public as Capital Power. Edmonton Councilor Don Iveson, now mayor, recognized that the city's ownership of significant generation capacity was risky - it had

volatile returns and was subject to changes in regulation (Iveson 2009b). Enmax provides electricity distribution outside Calgary and devotes 58 percent of its assets to generate electricity, which is sold into the province-wide grid (Enmax 2015). Similarly, taxpayers in Barrie, Markham, Vaughan, Hamilton, St. Catharines, and Mississauga will finance the cost of electricity infrastructure for Brampton and Richmond Hill through an upcoming merger, and a variety of smaller LDCs own part of the renewable energy generation capacity.

These expansions are financed by debt and equity. The equity portion comes from the particular LDC's profits that are not paid out as dividends - from retained earnings. If these retained earnings were paid out as dividends, they could be used to finance municipal services, lower property taxes, or fund the municipalities' capital investments - investments within their own jurisdiction. By holding shares in LDCs, municipalities incur an opportunity cost on their capital that cannot be ignored.

Municipalities have provided a rationale for this expansion by pointing to the benefits from expansion of renewable energy sources and the financial returns of these investments. If LDCs are pursuing these investments because they have attractive risk-adjusted returns, these investments could be financed by the private sector, which can sell power into the electricity grid at the same rates. This private capital would be provided voluntarily, while taxpayers do not have a choice when a municipality invests on their behalf. Municipalities should not be making risky investments which do not benefit their citizens with taxpayer assets.

\section{Discount Rates}

Investors use discount rates to compare the attractiveness of cash flows of varying riskiness at different points of time. Dollars that seem more certain and timely trump uncertain future dollars. A discount rate accounts for differences in timing and risk. For instance, at a 10 percent annual discount rate, investors do not care whether they receive $\$ 1$ today or $\$ 1.10$ one year hence. Municipalities have lower borrowing costs than private companies because of the implicit guarantee taxpayers provide to investors, which reduces the risk of the loan to the lender, but not the risk of the project (Boyer, Gravel, and Mokbel 2013). As a result, many argue that the city should use the cost of borrowing to discount the returns from investments in LDCs and other assets. The Capital 
Asset Pricing Model - used by the Ontario Energy Board (OEB) to determine an appropriate return on equity for LDCs - makes it clear that investors should use project-specific discount rates in evaluating risky investments regardless of the owner's actual cost of borrowing. A municipality's cost of borrowing accounts only for the much lower risk in lending to a municipality, not the risk in investing in an LDC. As an example, a privately traded utility would demand a higher rate of return on a risky investment in a technology startup, even though it can borrow much more cheaply.

The City of Toronto's (2016) analysis of a potential sale of Toronto Hydro fell victim to this fallacy. It identified that discounting future dividends at the OEB's allowable return on equity (ROE) rate means that a sale would generate positive returns to

\section{Box 1: Why Doesn't Toronto Invest in Bell?}

This calculation uses the same methodology to value a share of Bell (BCE) stock on November 24,2016 , as was used to value the city's stake in Toronto Hydro:

\begin{tabular}{lr}
\hline BCE quarterly dividend & $\$ 0.55$ \\
\hline $\begin{array}{l}\text { Current yield of 20-year City of } \\
\text { Toronto bond }\end{array}$ & $3.54 \%$ \\
\hline Effective quarterly yield & $0.87 \%$ \\
\hline $\begin{array}{l}\text { Present value of dividends at City } \\
\text { of Toronto cost of debt }\end{array}$ & $\$ 77.85$ \\
\hline $\begin{array}{l}\text { Current stock price } \\
\text { Willingness-to-pay premium }\end{array}$ & $\$ 57.95$ \\
\hline
\end{tabular}
taxpayers, while discounting at the city's cost of debt means that a sale would have negative returns to taxpayers. The OEB's ROE is the best estimate of an appropriate risk-adjusted discount rate for an equity investment in an LDC: it takes into account the uncertainty of the investment, while the city's cost of debt reflects the risk of making a loan to the City of Toronto, which can raise taxes to repay debt if necessary. The need for the city to make a $\$ 250$ million equity contribution to maintain Toronto Hydro's dividend and make needed capital investments demonstrates the risk. Therefore, the city should use the OEB ROE to discount future equity returns, and it should seek to sell if it believes it has other available investments that would earn higher risk-adjusted returns - financial or social. If we apply the methodology the city used to assess a sale of Toronto Hydro to a hypothetical purchase of Bell Canada shares by the city, we see that the city should be willing to pay a 35 percent premium to its market value (Box 1). This example illustrates the concern with using the city's cost of debt as a means of evaluating investments.

\section{What Canadians Own}

This analysis focuses on the value of Ontario's LDCs, EPCOR, and Enmax, contemplating the sale of shares to a private investor. Recent purchases of LDCs in Ontario by Hydro One, and Berkshire Hathaway's acquisition of AltaLink in Alberta, provide an indication of how institutional investors would likely value these companies (see Box 2 for detailed methodology). This analysis suggests that municipalities own equity stakes worth $\$ 15-\$ 20$ billion, a 58-115 percent premium over current book values (Table 1). This estimate is net of the value of existing debt, but prior to the intergovernmental transfers from transfer and departure taxes in Ontario. Toronto Hydro, the proposed GTA West LDC, Enmax, EPCOR, and the proposed GTA East LDC account for 79 percent of the total equity value - money that could be reinvested in municipal infrastructure projects. This analysis values total equity. If the municipality sold a partial stake, its returns would be commensurately lower. The recent purchases noted above occurred in a less competitive bidding environment because public-sector bidders have an advantage since sales to them are not subject to the transfer and departure tax regime. 


\begin{tabular}{|c|c|c|c|c|}
\hline LDC & $\begin{array}{l}2015 \text { Rate Base } \\
\text { (\$Millions) }\end{array}$ & $\begin{array}{c}\text { Value of Other } \\
\text { Power Business } \\
\text { (\$Millions) }\end{array}$ & $\begin{array}{l}\text { Net Debt } \\
\text { (\$Millions) }\end{array}$ & $\begin{array}{l}\text { Estimated } \\
\text { Equity Value } \\
\text { (\$Millions) }\end{array}$ \\
\hline Toronto Hydro & 4,188 & - & 2,171 & $3,700-5,400$ \\
\hline GTA West & 2,853 & Not significant & 1,292 & $2,700-3,800$ \\
\hline Enmax (Calgary) & 2,087 & $2,300-3,000$ & 1,680 & $2,900-3,600$ \\
\hline EPCOR (Edmonton) & 1,655 & 127 & 807 & 1,200 \\
\hline Hydro Ottawa & 812 & 250 & 572 & $800-1,100$ \\
\hline GTA East & 417 & Not significant & 200 & $400-550$ \\
\hline Other Ontario (51) & 3,108 & Not significant & 1,269 & $3,100-4,400$ \\
\hline Total & 15,121 & $2,600-3,300$ & 7,991 & $14,900-20,100$ \\
\hline
\end{tabular}

\section{Intergovernmental Transfers}

Municipally owned LDCs currently make payments-in-lieu of taxes (PILs) to their provincial government equivalent to what their corporate income tax liability would be. When sold, these LDCs begin paying corporate income tax, which in part flows to the federal government. Previously, the federal government did not receive any revenue streams from these assets. This section addresses the redistributive impact of these transfers.

\section{Alberta}

Enmax and EPCOR make PILs into the Balancing Pool, a provincial organization that manages power-generation purchase agreements. Any annual surplus is distributed to consumers as a bill rebate. If Calgary and Edmonton sold their LDCs, these PILs - averaging \$17 million per year since 2012 (Balancing Pool 2016) - would flow to the provincial and federal governments (Figure 2).

The impact of these PILs on consumer electricity bills is small, representing an average of 6 percent of the consumer rebate paid by the Balancing Pool. These payments declined to $\$ 4$ million (1 percent of rebate) in 2015 (Balancing Pool 2016) as the profitability of Enmax's generation division declined because of writeoffs associated with the cancellation of Power Purchase Agreements (Enmax 2015). The federal and Alberta governments should remit incremental tax revenues from LDC sales to prevent adverse impacts for consumers.

\section{Ontario}

Municipalities have hesitated to sell LDCs to private companies because of the provincial transfer and departure tax system. In the 1990s, when the province gave municipalities electricity assets, some of the associated debt was considered unsupportable by LDCs and placed in the Ontario Electricity Finance Corporation as stranded debt. PILs paid by LDCs are devoted to reducing this debt. A sale of municipal LDCs would transfer approximately $\$ 13.5$ million to the federal government, reducing revenues for the provincial government (Figure 3). 


\section{Box 2: Financial Valuation Methodology}

This valuation uses a standard five-step valuation methodology to establish indicative values for these electricity assets:

1. I determined a regulated rate base for each LDC using financial statements and the OEB Yearbook.

2. I calculated the ratio of total enterprise value (TEV) - the total value of debt and equity - to the regulated rate base for the set of six LDC acquisitions in Ontario since 2014 as well as Berkshire Hathaway's purchase of Altalink. The TEV / rate-base multiples were calculated separately by province because the provinces have different allowable rates of return and regulatory environments.

3. I established a valuation range of 1.4 to $1.8 \mathrm{x}$ TEV / rate base for Ontario based on a comparable transactions range, and a $1.125 \mathrm{x} \mathrm{TEV} /$ rate base for Alberta. This range includes all the relevant comparable transactions since 2014.

4. I valued other owned electricity-sector businesses by

- recording EPCOR's shareholding in publicly traded Capital Power at \$127 million per its 2016 third-quarter financials;

- valuing the hydroelectric facilities purchased by Hydro Ottawa from Fortis in 2015 at purchase price, and Hydro Ottawa's other generation at \$2.1 million per megawatt, the same rate it paid Fortis for hydroelectric facilities in Ontario; and

- valuing Enmax's generation business using the same TEV / Earnings before Interest and Taxes (EBITDA) multiple as Capital Power (a generation company with a similar asset base in Alberta) and at $\$ 1.5$ million per megawatt (the same rate it paid for its acquisition of the Cavalier and Balzac generating plants).

5. I applied multiples to the regulated rate base for each LDC to calculate the TEV, adding the TEV of other electricity-sector businesses and subtracting the book value of debt. Because of the ratesetting formula, LDCs are not exposed to interest-rate risk, so book value of debt, not market value, is the appropriate measure.

The estimated capital investment plan and the efficiency of operation, as well as the investor's perceived risk, will significantly influence the multiple of rate base an investor is willing to pay. Both these variables have significant uncertainty. A detailed market sounding should be conducted to estimate value.

To protect this revenue stream, the province assesses a transfer and departure tax on municipal LDCs that become subject to the corporate income tax. The transfer tax is assessed on the fair market value of assets, while the departure tax is assessed on recaptured depreciation and capital gains in the event of a sale (Fyfe, Garner, and Vegh 2013). In the 2015 Ontario budget, the province reduced the transfer tax for 2016 to 2018 to 22 percent for LDCs with more than 30,000 customers and eliminated it for smaller utilities, down from 
33 percent. It also exempted capital gains from the departure tax. These taxes will revert back to higher levels on December 31, 2018 (Ontario Ministry of Finance 2015).

This transfer and departure tax system means that even if municipalities use appropriate discount rates to value future dividends, these untaxed dividends would be more valuable than a sale subject to transfer and departure tax. While the Ontario LDCs are worth $\$ 11-\$ 15$ billion, the province would capture \$1.8-\$2.5 billion, leaving municipalities with $\$ 9-\$ 12.5$ billion (Figure 4). This provincial tax poses a significant barrier to any sale.

\section{How to Involve Institutional Capital Successfully}

Alberta and Ontario have regulatory environments designed to protect consumers from the abuse of market power by distributors and to regulate private LDCs elsewhere in their jurisdictions. However, the legislative environment makes selling equity stakes in these LDCs less attractive - by raising consumer prices in the event of a sale in Alberta, and by transferring resources from municipalities to higher levels of government in Ontario. Municipalities are therefore reluctant to sell, and that reluctance prevents this capital from being reinvested in priority infrastructure investments.

To address this problem, the federal government should provide a one-time bonus to the provinces equal to the present value of anticipated federal corporate taxes for any LDC sold to the private sector, so long as the proceeds of the sale are reinvested in qualifying infrastructure projects. Ontario should do the same - exempting municipalities entirely from transfer and departure taxes - if the proceeds of a sale are reinvested in qualifying infrastructure projects. These incentives would function the same way as Australia's Asset Recycling Initiative, where the federal government provided a 15 percent incentive payment to states which sold assets and reinvested the proceeds. This

\section{Figure 2: Budgetary Impact in Province of Alberta from Potential Enmax and EPCOR Sale, prior to recommended transfers}

Net Budgetary Impact from Sale (\$Millions annually)

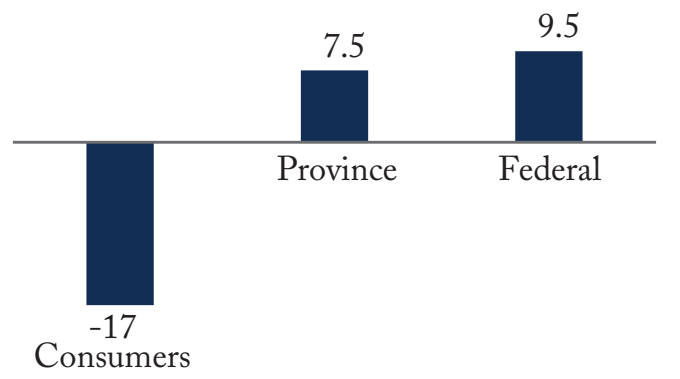

Source: Author's calculation from Balancing Pool Financials, 2012-15, based on average annual PILs paid.

\section{Figure 3: Impact on Tax Revenue from the Sale of Ontario Municipal LDCs}

2015 Pro Forma Tax Revenue

(\$Millions)

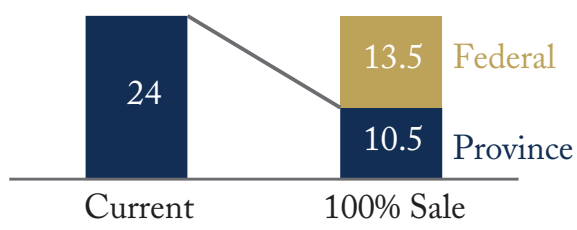

Source: Author's calculation from OEB, 2015 Yearbook of Electricity Distributors. 


\section{Figure 4: Distribution of Transfer and Departure Taxes, Ontario}

Distribution of Average Sale Proceeds (Ontario)

(\$Millions)

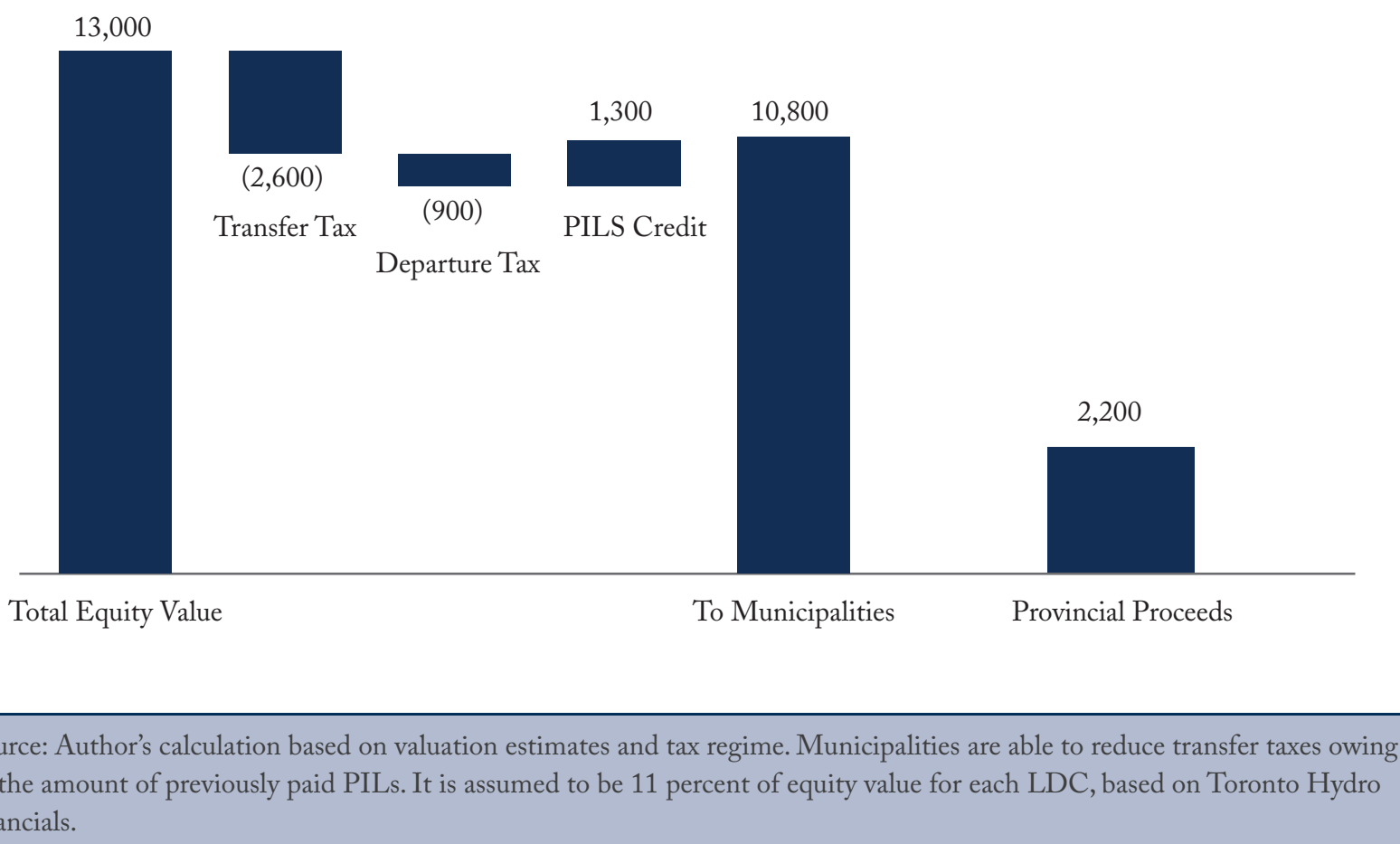

plan would mean the federal government would not benefit from new corporate tax revenues on LDCs sold to the private sector, but would would result in significant infrastructure investment, a key policy priority.

Alberta customers would see a small net reduction in their dividends from the Balancing Pool. A portion of the proceeds of the sale accruing to higher order governments through new taxes should be devoted to compensating consumers for this loss.

\section{Conclusion}

Municipally owned LDCs in Alberta and Ontario represent an asset worth \$15-\$20 billion for taxpayers in those cities. Municipalities should evaluate whether maintaining ownership in these assets best serves the interests of their taxpayers, or whether citizens would be better served by deploying this capital into high priority social and transportation projects. Meanwhile, Ontario should take the tax steps necessary to allow cities to receive the full value of their LDCs to invest in municipal priorities, removing the current disincentive to considering a sale. The federal government has the potential to catalyze these changes through an asset recycling initiative that would compensate provinces for the loss of the federal portion of corporate taxes. 


\section{References}

Balancing Pool. 2016. “Financial Reports 2012-2015.” http://www.balancingpool.ca/financial-reports/.

Block, Sheila. 2016. "Selling of Toronto Hydro: Private Sector Gain, Consumer Pain." Canadian Centre for Policy Alternatives. https://www.policyalternatives.ca/sites/default/files/uploads/publications/ Ontario\%20Office/2016/11/CCPA\%20ON\%20Selling\%20Toronto\%20Hydro\%20FINAL.pdf.

Boyer, Marcel, Eric Gravel, and Sandy Mokbel. 2013. “The Valuation of Public Projects: Risks, Cost of Financing and Cost of Capital.” Commentary 388. Toronto: C.D. Howe Institute. https://www. cdhowe.org/sites/default/files/attachments/research_papers/mixed/Commentary_\%20388_0.pdf.

City of Toronto. 2016. "Asset Optimization Review - Toronto Hydro Corporation and Toronto Parking Authority." City of Toronto. http://www.toronto.ca/legdocs/mmis/2016/ex/bgrd/ backgroundfile-98516.pdf.

Elston, Murray, Floyd Laughren, and David McFadden. 2012. "Renewing Ontario's Electricity Distribution Sector: Putting the Consumer First.” http://www.energy.gov.on.ca/en/ldc-panel/

Enmax. 2015. “Financial Review 2015.” https://www.enmax.com/AboutUsSite/Reports/2015-FinancialReport.pdf.

EPCOR. 2016. "Who We Are \&What We Do." http://corp.epcor.com/about/Pages/who-we-are.aspx.

Fyfe, Stephen, Mark Garner, and George Vegh. 2013. "Mergers by Choice, Not Edit: Reforming Ontario's Electricity Distribution Policy.” Commentary No. 376. Toronto: C.D. Howe Institute. https://cdhowe. org/sites/default/files/attachments/research_papers/mixed/Commentary_376_0.pd.

Hydro One. 2016. "Investor Relations." http://www.hydroone.com/InvestorRelations/Pages/Default.aspx.

Hydro Ottawa Holding Inc. 2015. “2015 Annual Report.” https://static.hydroottawa.com/documents/ publications/annual-report/2015-Annual-Report-EN.pdf.

Iveson, Don. 2009a. "What Can Happen When You Semi-Privatize Things.” Don Iveson. May 15. http:// doniveson.ca/2009/05/15/what-can-happen-when-you-semi-privatize-things/.

_. 2009b. “EPCOR: Risk and the Best Interests of the City.” Don Iveson. July 20. http:// doniveson.ca/2009/07/20/epcor-risk-and-the-best-interests-of-the-city/.

Kerin, Ryan. 2014. “Electricity Distribution in Australia.” IBISWorld. https://www.aer.gov.au/system/ files/F7\%20-\%20IBIS\%20World,\%20IBIS\%20World\%20Industry\%20report\%20D2630,\%20 Electricity\%20Distribution\%20in\%20Australia.pdf.

Kovach, Joelle. 2016. "Final Council Approval for PDI Sale.” Peterborough Examiner, December 16. http:// www.thepeterboroughexaminer.com/2016/12/16/city-council-votes-6-5-to-reaffirm-decision-to-sellpeterborough-distribution-inc-to-hydro-one-for-105m-after-5-12-hour-meeting.

National Academy of Sciences. 2009. In America's Energy Future: Technology and Transformation, 563-638. National Academic Press. 
OFGEM. 2013. “The GB Electricity Distribution Network.”June 18. https://www.ofgem.gov.uk/ electricity/distribution-networks/gb-electricity-distribution-network.

Ontario Energy Board. 2015. Yearbook of Electricity Distributors.

Ontario Ministry of Finance. 2015. “Transfer Tax.” http://www.fin.gov.on.ca/en/tax/ea/index.html. SEPP Capital IQ. 2016.

This E-Brief is a publication of the C.D. Howe Institute.

Steven Robins is a joint MBA and Master Public Policy Candidate at Harvard University.

This E-Brief is available at www.cdhowe.org.

Permission is granted to reprint this text if the content is not altered and proper attribution is provided. 